DOI: 10.46340/eppd.2020.7.3.9

Pavlo Bohutskyi, PhD in Law

ORCID ID: https://orcid.org/0000-0003-3537-6991

Scientific Research Institute of Informatics and Law of the National Academy of

Legal Sciences of Ukraine

\title{
THE NATIONAL SECURITY LAW \\ IN THE SYSTEM OF NATIONAL LAW: \\ THE PROBLEM OF CONCEPTUALIZATION AND ITS SOLUTION
}

The article deals with the problem of conceptualization of national security law as systemic integrity within the national legal system. This problem is relevant, uncharted in jurisprudence in general, and in general theoretical jurisprudence in particular since it concerns the definition of national security law as a separate branch in the system of law, the interaction of law and the state, the establishment of appropriate national security concept of law. The conceptualization of national security law is carried out through the recognition of the empirical basis of national security with its subsequent ontological interpretation in the legal dimension, as a result of the formation of a scientific concept. The conceptualization of national security law is realized through an awareness of the empirical basis of national security and its subsequent ontological understanding in legal terms on the basis of appropriate methodological approaches, which results in the formation of a scientific concept. The conceptualization of national security law is a complex way of reflecting on the important conditions for each individual and for society as a whole, the safe conditions of life and social existence provided by the state and civil society institutions on the basis of the requirements of law. The result of such reflection is the legal determination of the possibilities and ways of safe human life, sustainable democratic development in the conditions of protection against real and potential threats to national interests and determines the formation in the system of national law of a separate branch of law, which is the national security law on the basis of interaction with international public law.

Keywords: national security, conceptualization of national security law, civil society, state sovereignty, ontology of national security law, normative and axiological basis of law, legal strategic culture, legal strategic thinking, integrity of national security law, concept of national security law.

Introduction. The concept of Ukrainian national security law, as one of the pressing problems of modern jurisprudence, requires complex scientific study in order to establish the empirical basis, to determine a certain set of norms that belong to the national system of law and operate in a particular field. At the same time, the national security law of Ukraine requires a scientific substantiation of its own subject, content, functions and place in the system of law, and therefore its corresponding conceptual certainty.

The purpose of the article is to reveal the features of the conceptualization of national security law as an independent branch in the system of national law and to determine its relations with other entities of the national legal system and with international law.

State of the problem research does not give grounds for the conclusion about the numerous scientific developments of the problem of national security law, but indicates the disclosure of certain legal theoretical and applied aspects of national security in the works of O. Danilian, O. Djoban, V. Pilipchuk, M. Strelbitskyi, V. Lipkan, O. Dovgan, O. Baranov, I. Doronin and other scientists.

The conceptualization of national security law is primarily in recognizing the empirical basis of national security, followed by its ontological understanding in legal terms, on the basis of appropriate methodological approaches, which results in the formation of the concept ${ }^{1}$.

\footnotetext{
${ }^{1}$ Богуцький, П.П. (2018). Поняття та ознаки права національної безпеки України. Інформація і право, 3 (26), 84-91.
} 
The empirical basis of national security law is the totality of complex and important social factors that ensure human security, society and the state in the conditions that characterize globalization processes $^{1}$.

The ontological basis of national security law. National security for Ukraine, as for every modern society and every state, is a problem whose solution allows one to successfully exist in the social space on the basis of sustainable development in all spheres of human life ${ }^{2}$.

In modern conditions, the problem of national security is solved in the circumstances, which are due to many states the need to protect sovereignty and territorial integrity from military aggression. This problem was very urgent for Ukraine because of the historical prerequisites for the formation of the state, as well as due to the active and diverse political, economic and military activities of the Russian Federation in order to limit the sovereignty of the Ukrainian state after independence in 1991.

Today should acknowledge no law in general and Ukrainian legal science, in particular, of a holistic concept of national security law. Some, including those relating to conceptual developments, have been carried out in many legal systems where national security problems are solved or successfully solved taking into account the real security status of the societal environment in which states are located, exercising state and national sovereignty.

First of all, any development of national security law issues must take into account the priority of legal security of national security, which corresponds, in fact, to the purpose of law. In these circumstances, the legal support for national security appears in various institutional and functional levels in different sectors and industries, with a basically certain legal model.

It is clear that for many countries, including Ukraine, it is relevant to use the experience of the most effective solution to the issue of legal support for national security, which takes place in the countries belonging to the North Atlantic Treaty Organization, first of all, this concerns the legal model of national security of the USA. Developments by scientists at leading US universities and research centers are based on practical material and actions taken and implemented by the state to address and anticipate national security threats. The US national security doctrine is based on the Constitution, the provisions of the National Security Act of 1947 and the National Security Strategy ${ }^{3}$ and demonstrates convincingly that the national security law of any state must take into account the peculiarities of national public relations, those social communications that have developed and are formed within the existing legal system and are based on economic, political, military, information, technogenic and other characteristics. Such characteristics or indicators cannot be a repetition of those existing in other legal systems, but their accounting and use are obligatory, since national security and, consequently, national security law, are formed within the framework of world order. The most important are the linkages of national security law with constitutional, military law, as well as with international law (international security law, international criminal law, international humanitarian law), which leads to the unification of doctrinal developments, to the formation of common approaches in law-making and in law enforcement.

Scientists declare a certain culture of security, a kind of stylized culture, which in turn influences the formation of a particular model of national security 4 .

In its practical solution, a stylized security culture contains a geopolitical, a liberal-democratic (liberal peace approach) and an anti-terrorist approaches to national security that influence the definition of national security goals and places of law in achieving national security goals, including the application of international and national justice systems, law enforcement activities ${ }^{5}$. It is important that these models of national security under the present conditions are influenced by various social factors, are changing and demonstrating a departure from overt statism in addressing human rights issues.

\footnotetext{
${ }^{1}$ Горбулін, В.П. (2017). Національна безпека як пріоритет сучасного державотворення. Вісник Націіональної академії наук України, 1, 25-29.

${ }^{2}$ Власюк, О.С. (2016). Національна безпека України: еволюція проблем внутрішньої політики: Вибрані наукові праці. Київ: НІСД, 78-86.

${ }^{3}$ National Security Strategy of the United States of America (2017). President of the USA.

$<$ https://www.whitehouse.gov/wp-content/uploads/2017/12/NSS-Final-12-18-2017-0905.pdf $>$.

${ }^{4}$ Chinkin, Ch., Kaldory, M., Rangelovz I., Weill, Sh. (2016). Special Issue: Law, Justice and the Security Gap.

Journal of Conflict \& Security Law, 21, 1, 1-7.

${ }^{5}$ Chinkin, Ch., Kaldory, M., Rangelovz I., Weill, Sh. (2016). Special Issue: Law, Justice and the Security Gap.

Journal of Conflict \& Security Law, 21, 1, 1-7.
} 
National security in its ontological meaning characterizes a certain idea of a person about the conditions of his life, about the conditions of existence of society, the state and, at the same time, presents a deliberate and purposeful activity aimed at ensuring the sustainable existence and development of a person, society and the state. Ontological dualism, which manifests itself in the interdependence of human security and the security of society, is confirmed by the empiricism of social relations, social communications, regulated by a set of law norms. It is under these conditions that an appropriate model of the legal content of national security is formed.

The ontological intersection of national security and law reveals that national security loses any meaning without state involvement, namely, defined by the Constitution and the legislation of state institutions, in particular, the Armed Forces and other entities formed in accordance with the laws of the military formations, state special purpose bodies with law enforcement functions, law enforcement and intelligence agencies and other subjects of the security and defence sector. That state institutions are active driving factors of national security through the operation of national security which takes its meaningful meaning. Law constitutes a certain essential area of national security, approving its form and civilizational features contained in the norms of law in legal communities consolidated under the relevant legal regime.

Consequently, the conceptual understanding of national security law is to reveal the ontological significance of the empirical background to the safe state of person, society and the state, as well as activities to achieve this status and in the essential perception of the relationship between law and state, which is extremely important. The formation of the legal content of national security and the acquisition of national security of a certain legal form occurs in a complex cognitive process, resulting in the formation of an appropriate strategic culture. If the security culture is the epitome of relevant understandings and actions to ensure national security as defined by the law of governmental institutions then strategic culture spans a wider social space in which the reflection of social belonging to a certain society, the person's perception of public requests and needs, the understanding of national interests and the translation of such understanding in behavioural acts. Strategic culture can be considered as common, inherent to all or most of the people belonging to society, as well as special or professional, possessed by trained national security experts. In this sense, it is quite appropriate to conclude that a special strategic culture is formed in the field of national security of the US military elite where the Military Academy at West Point and the National Defense University are of particular importance when training is compulsory for the careers of any top-level commander, and therefore US military professionals are regarded as a certain caste with their own values and ideals, norms that are required ${ }^{1}$. At the same time, when it comes to making appropriate decisions in the field of national security, a strategic culture acquires a sign of strategic thinking ${ }^{2}$.

It is clear that strategic culture and strategic thinking in the field of national security have the appropriate legal form therefore legal strategic culture and legal strategic thinking can be argued as reflecting on the legal aspects of national security understanding, actions or decisions. However, it is important to conclude that strategic culture and strategic thinking need to be adapted to the whole socialcultural space in general and the legal cultural space in particular. The mechanism of conformity of strategic culture and strategic thinking (legal strategic culture and legal strategic thinking) is based on fundamental ideas, values and institutions of civil society.

Significant is the fact that the formation of civil society, the achievement of the general social security, which is national security, the formation of a legal holistic community - national security law occurring in one plane and one temporal coordinates. In this way, it is important to balance the requests of all social actors for safe living conditions, to prevent possible conflicts and to resolve existing contradictions on the basis of general importance, universal standards and values contained in law.

The interaction of law and state in ensuring national security. Law combines the efforts of all social actors to solve the problem of national security, and this complex process occurs even in the face of opposition, but more successfully - in the unity and understanding of the need to obey the security standards defined by law. This, in fact, is seen as an important purpose of national security law.

\footnotetext{
${ }^{1}$ Рыхтик, М.И. (2003). Концептуальное осмысление национальной безопасности США: республиканский подход и его воздействие на процесс государственной внешнеполитической стратегии (исторические аспекты проблемы). Вестник Нижегородского университета им. Н.И. Лобачевского, 1, 78.

2 Рыхтик, М.И. (2003). Концептуальное осмысление национальной безопасности США: республиканский подход и его воздействие на процесс государственной внешнеполитической стратегии (исторические аспекты проблемы). Вестник Нижегородского университета им. Н.И. Лобачевского, 1, 78.
} 
However, the consolidation of the actions of such social actors as society (civil society institutions), the state (public authorities) and person (individual and collective entities) is perhaps not an ideal situation that is clearly characterized by the successful resolution of national security tasks which is able to realize a strong state ${ }^{1}$.

The point is that the attitude of the state, state institutions, civil society and its institutions to the primacy of law in solving the national security problem is not straightforward. The state constantly asserts its claims for domination in the field of national security, and the practice of activity of specific state institutions, the consequences of the exercise of the functions and powers defined by the law by them, indicate that the state and appropriate political management often exaggerate the possibilities of public power, including the establishment certain rules of conduct in the field of national security, which leads to abuse of law and powers and causes social conflicts. In turn, the civil society institutions and the public associations can also act against the requirements of law and applicable law to achieve their goals. Ignoring legal requirements by government or civil society institutions leads to a clear pattern of law, which leads to a tangible social vacuum, where the deficiency of law becomes tangible and, consequently, the task of ensuring national security in general and in specific areas has no prospect of a successful solution. This situation can be overcome by approximating the law and the state and determining exclusively the legal content of the state and civil society institutions in all areas of national security. In these circumstances, national security law, as a systemic legal integrity, becomes of great importance.

It should be noted that national security law is, first and foremost, a complex social construct whose ontological significance is in need of search, given the impossibility of identifying such generalizations that would be based exclusively on empirical material. At the same time, the empiricism of national security itself is quite accessible to cognition as a result of the disclosure of security features that are important at the individual and general (generalized) levels. The transition from the empirical perception of security to the ontological meaning of national security is necessary in building the concept of national security law as structured in a legal system of integrity.

The areas of national security are multi-vector, which is related, first of all, to the diversity of social life and the diversity of requests of collective social actors and individuals in the context of ensuring safe living conditions. However, it is worth agreeing with the well-established position regarding the determining directions on which national security issues are based - sovereignty, territorial integrity, constitutional order, safe living conditions. That is why the issue of effective legal regulation of the activities of the subjects of the security and defense sector at national and international levels is of paramount importance. Questions regarding the activities of these entities are important in shaping the concept of national security law and identifying its attributes for several reasons. First of all, it is about the separation of subjects of national security law such as the state and civil society. This kind of statement leads to a generalization that harms the definition of the content of legal communications (legal relationships) precisely because of the excessive level of generalization and some abstraction. However, without such a generalized approach and its application in applied research, it is impossible to determine the essence of a legal entity as a certain absolute ${ }^{2}$.

The grounds for claiming the primacy of the law in national security are subject to critical reflection, but confirm their rationality and truth. It is clear that the law contains normative and value indicators, which in their entirety allow ensuring the stability of the environment created by the interaction of society and the state, which is important for the individual, civil society and the state. At the same time, the law establishes procedural and substantive standards regarding the behavior of national security entities, defines and approves national social values that are subject to legal protection and provides such protection.

Meanwhile, it should be borne in mind that in the field of national security, the emergence and real existence of contradictions between social institutions, between civil society and the state is an issue that is constantly open for debate and resolution. The resolution of such contradictions activates most of the destruction of the foundations of national security. That is why the role of legal mechanisms for overcoming and resolving conflicts and contradictions between social needs and state capacities, provided

\footnotetext{
${ }^{1}$ Ударцев, С.Ф. (2019). Сильное правовое государство и новые вызовы безопасности: вопросы теории. Право и государство, 1-2 (78-79), 4-22.

${ }^{2}$ Хаустова, М. (2009). Суб'єкт права як елемент правової системи суспільства. Вісник Академії правових наук України, 3, 29-38.
} 
with the appropriate power mechanisms, which should receive legal content, is actualized ${ }^{1}$. Such legal mechanisms of the government require the effective control of the activities of the state institutions in the field of national security, which are relevant to the security and defense sector. Democratic civilian control, including civil society control, carried out in accordance with the prescriptions of national security law by civil society institutions, is recognized as the most effective.

The national security law in resolving social and legal conflicts has an inherent ability to secure a legal compromise. It is worth agreeing with S. Bobrovnyk stating that legal compromise is a mediated legal form, a value-oriented means of ordering a conflict based on the mutual concessions of participants in public relations, the purpose and result of which is a state of public consent and the consolidation of democratic values in society ${ }^{2}$.

Particular attention should be paid to the fact that the process of ontological comprehension of the empirical primary data on the safe conditions of human being depends entirely on the conscious attitude of the person and his participation in the further formation, implementation of normative and value-based arrangements regarding national security. Without awareness of the numerous circumstances that constitute the causes, conditions, content of the social state of security of one's existence in the societal environment, any ideas, and even more so, actions concerning the normative value justification of national security, which is the national security law, lose their ontological meaning and practical meaning. Meanwhile, the subjective right of a person to safe living conditions becomes important, forcing another to consider the implementation of the relevant constitutional provisions in the national security law, namely the initial, fundamental ideas regarding the legal status of the individual and the citizen.

The national security law has its own objects, the definition of which depends directly on the content of national security. Objects of the national security law are national interests.

National interests are determined not only by the state but also by society as a whole, and they need legal definition and protection.

The formation of national security law, as an integrated system of plurality rules of law, is largely nonlinear in nature and depends on the objective social need for normative and legal ordering of social relations (social communications) in order to achieve the goal of safe living conditions for the human being and the existence of society and the state.

National security is subject to the normative and value influence of law and, of course, is a holistic system formation, confirming the rule that it is necessary to form not only the general security status, but also - in every sphere of human activity without exception.

Consciousness does not allow one to perceive national security without forming a holistic view ${ }^{3}$. Reflection on national security is due to an awareness of the overall picture of security and, at the same time, to the specification of areas of the security environment.

An understanding of the law and its systemic features must be considered important in building the concept of national security law as a whole. The ontological significance of the legal integrity of national security demonstrates certain regularity. The point is that law not only sets normative, general social requirements and provisions regarding national security. Law produces an active force to protect the common social interests that appear in the paradigmatic context of national security as national interests. Here, in this combination of law and national security, on the relative perception of the ontological characteristics of the concept of national security law, new possibilities of knowing the legal form of national security are opened.

The normativity of law and the axiological basis of law are indispensable in shaping the social structure of national security, which is reflected in consciousness, and, at the same time, it is the result of the practical activity of social actors, where the most tangible, despite the practice of particular individuals, is the role of state institutions. The concept of national security law as a whole thus receives its value base and completeness of the normative form.

\footnotetext{
${ }^{1}$ Богуцький, П.П. (2018). Поняття та ознаки права національної безпеки України. Інформація і право, 3 (26), 84-91.

2 Бобровник, С.В. (2011). Компроміс і конфлікт у праві: антрополого-комунікативний підхід до аналізу, Київ: Вид-во «Юридична думка», 330.

${ }^{3}$ Chandra, S., Bhonsle, Rahul K. (2015). National Security: concept, measurement and management. Strategic analisys, 39, 337-359.
} 
The value base of national security contains a large number of the most important for society and human interests, the achievement of which brings social existence to a level accessible to meet their own needs, due to the need for sustainable development. In this sense, the axiology of national security looks multifaceted, moving from one quality of existence of person and society to another, combining the values of spiritual and material origin, revealing itself in the direction from individual characteristics to general ones, demonstrating the presence in the center of human value reality and its needs. In such circumstances, the law becomes indispensable in determining the form and content of activities to meet the needs for safe living conditions, in the safe existence of society as a whole.

The value pattern of being is sufficiently variable; having its own specific characteristics depending on time and place, on the state of the societal environment, on the conditions that have developed during a historical period in a particular society, and which determine the life of a person. At the same time, the value picture of social existence exhibits certain constant indicators that remain unchanged and, therefore, attributable to fundamental values. Among these values is, first of all, the value of life, the formation of such the natural environment of human existence, where the indicators of the standard of living are not dependent on its activity, or the human activity ceases to create obstacles for the safe and successful existence of both the individual and the whole human generations. Persistent and in need of constant attention are the values of sovereignty, territorial integrity, which concern not only the states, society but also the person within its societal space. In its own, law responds to the satisfaction of human security values, such a response is not limited to the formation of regulatory requirements, and allows regulatory requirements to adapt to the value requests of the individual, social groups and society as a whole.

Conclusion. The conceptualization of national security law is a complex process that involves the reflection of safe, vital conditions for each individual and society as a whole. The result of such reflection is the legal identification of opportunities and ways of sustainable development in the conditions of protection against real and potential threats to national interests. National security law is formed as systemic integrity, as a separate branch within the national system of law in cooperation with other branches of national law and with clearly defined, regular links with the international legal system, which is dependent on permanent, legitimate, due to permanent and comprehensive globalization processes. The national security law passes a difficult path of development from a worldview perception of the foundations, areas of interaction, the interdependence of law and the state, from the emergence of the idea of an independent branch of law to the formation of an appropriate concept, which is subject to further scientific development. At the same time, conceptually important is the resolution in the national security law of the problem of common interests of the state and society, which is reflected in the national interests that are subject to protection, and that can be effectively implemented in the conditions of a strong state. At the same time, the qualitative features of a strong state are ensured by the national security law while addressing the challenges of developing civil society and strengthening the legal potential for protecting human rights and freedoms. The national security law allows expanding the cognitive possibilities of legal support for protecting the sovereignty of the state and to realize such opportunities in law-making and law enforcement practice. An important factor is the strengthening, due to national security law, of the legal potential of the organizational and functional aspects of the state security and defense sector, which, however, refers to the possibility of further scientific research.

\section{References:}

1. Bobrovnyk, S.V. (2011). Kompromis i konflikt u pravi: antropoloho-komunikatyvnyi pidkhid do analizu [Compromise and conflict in law: an anthropological-communicative approach to analysis]. Kyiv: Iurydychna dumka. [in Ukrainian].

2. Bohutskyi, P.P. (2018). Poniattia ta oznaky prava natsionalnoi bezpeky Ukrainy [The concept and features of national security law of Ukraine]. Informatsiia i pravo [Information and law], 3 (26), 84-91. [in Ukrainian].

3. Vlasiuk, O.S. (2016). Natsionalna bezpeka Ukrainy: evoliutsiia problem vnutrishnoi polityky [National Security of Ukraine: Evolution of Domestic Policy Problems]. Vybrani naukovi pratsi [Selected scientific works]. Kyiv: NISD, 78-86. [in Ukrainian].

4. Horbulin, V.P. (2017). Natsionalna bezpeka yak priorytet suchasnoho derzhavotvorennia [National security as a priority of modern state formation]. Visnyk Natsionalnoi akademii nauk Ukrainy [Bulletin of the National Academy of Sciences of Ukraine], 1, 25-29. [in Ukrainian].

5. Ryhtik, M.I. (2003). Konceptual'noe osmyslenie nacional'noj bezopasnosti SShA: respublikanskij podhod i ego vozdejstvie na process gosudarstvennoj vneshnepoliticheskoj strategii (istoricheskie aspekty problemy) [Conceptual understanding of US national security: a republican approach and its impact on the process 
of state foreign policy strategy (historical aspects of the problem)]. Vestnik Nizhegorodskogo universiteta im. N.I. Lobachevskogo [Bulletin of the Nizhny Novgorod University. N.I. Lobachevsky], 1, 78. [in Russian].

6. Udarcev, S.F. (2019). Sil'noe pravovoe gosudarstvo i novye vyzovy bezopasnosti: voprosy teorii [Strong rule of law and new security challenges: theory questions]. Pravo i gosudarstvo [Law and State], 1-2 (78-79), 4-22. [in Russian].

7. Khaustova, M. (2009). Subiekt prava yak element pravovoi systemy suspilstva [The subject of law as an element of the legal system of society]. Visnyk Akademii pravovykh nauk Ukrainy [Bulletin of the Academy of Legal Sciences of Ukraine], 3, 29-38. [in Ukrainian].

8. Chandra, S., Bhonsle, Rahul K. (2015). National Security: concept, measurement and management. Strategic analisys, 39, 337-359. [in English].

9. Chinkin, Ch., Kaldory, M., Rangelovz I., Weill, Sh. (2016). Special Issue: Law, Justice and the Security Gap. Journal of Conflict \& Security Law, 21, 1, 1-7. [in English].

10. National Security Strategy of the United States of America (2017). President of the USA. $<$ https://www.whitehouse.gov/wp-content/uploads/2017/12/NSS-Final-12-18-2017-0905.pdf > . [in English]. 